\title{
Was Italy a protectionist country?
}

\author{
GIOVANNI FEDERICO $†$ AND ANTONIO TENA \\ † Dipartimento di Storia Moderna e Contemporanea, Università degli studi di \\ Pisa, Piazza Torricelli, 3/A, 56126, Pisa, Italy. \\ $\ddagger$ Departmento de Historia e Istituciones Economicas, Universidad Carlos III, $\mathrm{cl}$ \\ Madrid 126, Getafe 28903, Spain.
}

\begin{abstract}
This paper aims at measuring as precisely as possible the changes in the level of protection in Italy from the 1870 s to the 1920 - i.e. during the first phase of the country's industrialisation. It shows that, contrary to conventional wisdom, protection was quite low - with the possible exception of a short spell of time in the late 1880 os-9os. Therefore the static welfare losses were small, but also the alleged dynamic role of protection in fostering industrialisation seems small as well. In the last section of the paper we speculate on the implications of these findings for other countries. This evidence is not conclusive, but it does cast some doubts on the relevance of protection in 19th century Europe.
\end{abstract}

\section{Introduction}

Trade policy has always been one of the most controversial issues in European economic history. After a brief spell of free trade in the 1850 s-70s under British influence, most countries on the Continent reverted to their traditional protectionism, which was to last until the disintegration of world trade in the I930s. Some authors - notably Bairoch (1976, 1989, 1996) - praise this policy as instrumental to the development of Continental Europe. Without protection, many industries would not have withstood the British competition. This opinion, possibly in a less extreme form, seems to prevail also in case-studies by country, including Italy (Sapelli I99I, Zamagni 1994). However, several scholars are not convinced of the wisdom of protectionism. Italian trade policy has been criticised by, among others, Gerschenkron (I962) and Fenoaltea (1973, I993). In a broader vein, Pollard (1982) sees the return to protection in Europe during the 1880 s as a component of that trend towards disintegration which was to have very dire consequences for the Continent, at least in political terms. In spite of these differences, all authors agree that trade policy did affect deeply the timing and the pattern of European industrialisation. The only exception to this conventional wisdom is Capie, who has recently argued that protection was low and 'did not have a significant economic impact on the economies in which it was introduced' (Capie 1994, p. 55; see also Capie 1983). In a nutshell, protection can be seen in three different ways - as high and beneficial, high and harmful, low and not so relevant. Which is the right story? 
The question is a very difficult one, as economic theory has not yet provided a really satisfactory method for dealing with trade policy. It is possible to estimate its static effects, but the dynamic ones, the most interesting in historical perspective, remain quite elusive. However, the available best practice has not yet been applied to historical data. Even the level of protection (was it high or low?) is not well known. There are some estimates, but they are scattered, not homogeneous and encumbered by a host of measurement problems. Most historians therefore rely on anecdotal evidence, such as the statements by contemporaries or the history of trade policy. It is assumed that a country became protectionist only because it approved a tariff law. Such an inference is clearly not a satisfactory basis for the overall assessment of the effects of the policy. It should be substituted by some quantitative estimate, and this article is the first step in this direction.

This article aims at measuring as precisely as possible the changes in the level of protection in Italy from the 1870 s to the 1920 - i.e. during the first phase of the country's industrialisation. The next section reviews the measurement problems and suggests a new accounting method for analysing the changes in nominal protection. Section 3 presents the results and discusses the consistency of different measures. It shows that protection was not very high and it was concentrated on 'fiscal' products. The fourth section explores the effects of protection. First it estimates tentatively the (low) welfare losses. Then it discusses briefly the likely effects of the different rates of effective protection on the allocation of resources, which are dealt with in more detail in a companion paper (Federico and Tena 1997). It sems unlikely that the structure of protection favoured industry. The last section of the article speculates on the implications of our findings for other countries - Europe in the Italian mirror, to paraphrase the title of Gerschenkron's well-known book.

\section{How to measure protection}

Measuring the level of protection is comparatively easier in the I9th century than nowadays. In fact, before the Great Crisis of the I930s quotas or other non tariff barriers (NTB) were almost unknown. Protectionist policy relied exclusively on duties, whose effects are much simpler to assess. A duty causes the domestic price of each commodity to increase over the world price by an amount equal to the duty itself. 'The duty may be expressed as a percentage of the world price (ad valorem duty), or, as in Italy and in most countries of Continental Europe, as a fixed sum per unit of weight (specific

\footnotetext{
${ }^{1}$ In principle, the difference between the two prices might be lower than the full amount of the tariff (so called watered protection). However this case is not relevant in empirical analysis because these goods are not imported, as they would cost more than domestic production.
} 
duty). In the latter case, the ad valorem equivalent (for comparative purposes) has to be computed as:

$$
\mathrm{Ti}=\mathrm{Di} / \mathrm{Pi}
$$

where $D i$ is the specific duty and $P i$ the world price for sector $i^{2}$ In most empirical work, the figures on specific duties are taken from tariff laws. This ex ante measurement may not be accurate if some goods are imported under special regimes, such as bilateral tariff agreements, differential tariffs during trade wars or exemptions (e.g. on temporary imports). Therefore, the rates are better computed ex-post as the ratio of customs revenues to total value of imports for each good:

$$
\mathrm{Ti}=\left(\mathrm{Q}_{\mathrm{i}} \times \mathrm{D}_{\mathrm{i}}\right) /\left(\mathrm{Q}_{\mathrm{i}} \times \mathrm{P}_{\mathrm{i}}\right)
$$

where $Q i$ is the quantity of imports of the $i$ th good.

So far, so good. The real problem is how to aggregate the single duties into an economy-wide measure of protection (Vousden 1990, Greenaway and Milner 1993). In principle, the duties should be weighted with the composition of imports which would have prevailed under free trade. Unfortunately, this composition is not observable and, in spite of some recent advances, economic theory has not yet provided a really satisfactory proxy. There are five possible alternatives:

(I) No weighting at all (simple average of duties across sectors, where $i=\mathrm{I} \ldots n)$ :

$$
\mathrm{UNT}=\sum \mathrm{T}_{\mathrm{i}} / \mathrm{n}
$$

(2) The actual structure of trade:

$$
\mathrm{NT}=\sum \mathrm{r}_{\mathrm{i}} \mathrm{T}_{\mathrm{i}}
$$

where $r_{i}$ is the share of the $i$ th good in total imports. By definition it can be computed by dividing the total customs revenue by the value of imports:

$$
\mathrm{NT}=\Sigma\left(\mathrm{Q}_{\mathrm{i}} \mathrm{D}_{\mathrm{i}}\right) / \Sigma\left(\mathrm{Q}_{\mathrm{i}} \mathrm{P}_{\mathrm{i}}\right)
$$

(3) The percentage of domestic output $w_{i}$ or of consumption $z_{i}$ of tradables:

$$
\begin{aligned}
& N T W w=\sum w_{i} T_{i} \\
& \text { or NTWz }=\sum z_{i} T_{i}
\end{aligned}
$$

(4) The composition of trade of the same country in a previous year, as suggested by McCloskey (I980):

${ }^{2}$ It has been argued (Anderson 1995, Feenstra 1995) that protection should be computed on the basis of domestic prices inclusive of duties - i.e. as $T^{\star}{ }_{i}=D_{i} /\left(P_{i}+D_{i}\right)$. The difference in the case at hand was small, as the duties were low, and therefore we will follow the traditional definition to make our data comparable with other estimates. 
$\mathrm{RNT}=\Sigma\left(\mathrm{Q}_{\mathrm{it}-\mathrm{I}} \mathrm{D}_{\mathrm{it}}\right) / \Sigma\left(\mathrm{Q}_{\mathrm{it}-\mathrm{I}} \mathrm{P}_{\mathrm{it}-\mathrm{I}}\right)$

which is conceptually equivalent to a Laspeyres price index, exactly as NT is a Paasche price index.

(5) Some other vector of trade flows, such as the composition of British exports (Board of Trade 1905), or of a sample of major countries (Liepmann 1938) or the structure of total world trade (Balassa 1965).

It is well known that NT usually biases the results downward to the extent that duties reduce imports of the protected goods. The extent of the bias depends on the level of the duties and on the elasticity of imports of the most important goods. A country which imposes prohibitive tariffs on all goods but one (imported free) would appear less protectionist than another which raises a uniform 5 per cent duty. But the other measures may be biased as well. UNT assumes that each item had the same share in consumption, which is clearly implausible. The bias is (roughly) inversely proportional to the number of products (Tumlir and Till 197I), which depends on the lay-out of trade statistics. Usually, they are more detailed for manufactures, which may therefore be given an excessive weight. ${ }^{3}$ The two NTW measures may be biased because the duties affect domestic production and consumption as well. If, as is likely (but not certain), protection raises the percentage of protected goods in output and lowers that in consumption, the two measures would be biased in opposite directions. NTWw would overestimate the rate of protection and NTWz would underestimate it. Finally, the last two measures are also dubious. There is no reason why the composition of world trade (or of British exports) should be close to the ideal 'free-trade' imports of a given country, with its specific resource endowment and level of development. RNT is possibly the most appealing measure, provided it were possible to find a 'free-trade' year close enough to the relevant one. However, this condition is hardly ever met in historical research, as the protectionist policy lasted for decades, while the economies were changing.

Even a 'perfect' weighting, were it possible, would not be sufficient. In fact it would be a partial-equilibrium approach, which measures only the proximate effects of trade policy on the market for each good. One should take into account also the indirect effects via the prices of inputs in a general equilibrium framework. This idea has been embodied recently by Anderson and Neary (Anderson 1994, Anderson and Neary 1994, 1996) in the trade restrictiveness index (TRI). It is defined as 'the uniform tariff factor (domestic price) deflator, which, applied to the new tariff factors, permits the initial level of utility of the representative consumer to be supported in

${ }^{3}$ In this research, the bias is minimised by a two stage computation - i.e. first computing the UNT for 4- or 5-digit aggregates (irrespective of the actual number of products they are composed of) and then the average UNT. 
general equilibrium' (Anderson 1995, p. I60). In other words, it measures the percentage change in the (uniform) tariff which is equivalent to the actual tariff change maintaining the same level of welfare. ${ }^{4}$ TRI is theoretically very sound, but its computation is encumbered by a major practical shortcoming - the need to know the elasticities of substitution and transformation. These parameters are not available in historical analysis, and therefore they have to be substituted by assumptions. O'Rourke (1997) has shown that the results may be quite sensitive to assumptions about the pattern of substitutability and about the values of the elasticities. ${ }^{5}$

Therefore, there is as yet no ideal solution to the problem. The 'true' level of protection at any given point in time cannot be ascertained. The best practical compromise seems to be to compute all the measures and assess their consistency. This strategy yields a further bonus, as the comparison between different measures provides an insight into the causes of changes in the level of protection. Usually, the variations are attributed to changes in trade policy, but this is not necessarily the case. The overall level of protection can also change if duties remain constant, either because the composition of trade varies (as a result of trade policy itself or for any other reason) or - in the case of specific duties - because world prices change.

It is possible to disentangle these three causes, by computing:

$$
\begin{aligned}
& {\left[N T_{t}-N T_{t-1}\right]=\left[N T_{t}-R N P_{t}\right]} \\
& \quad+\left[R N P_{t}-R N T_{t}\right]+\left[R N T_{t}-N T_{t-r}\right]
\end{aligned}
$$

where NT is defined as in (4b), RNT as in (6) and RNP as:

$$
\mathrm{RNP}=\Sigma\left(\mathrm{Q}_{\mathrm{it}-\mathrm{I}} \mathrm{D}_{\mathrm{it}}\right) / \Sigma\left(\mathrm{Q}_{\mathrm{it}-\mathrm{I}} \mathrm{P}_{\mathrm{it}}\right)
$$

Each component on the right-hand side of equation (7) measures how much aggregate protection (NT) would have changed ceteris paribus. The first component, or duty effect, estimates the variation that would be caused by a change in tariffs with unchanged world prices and composition of imports i.e. the effects of trade policy. The second, or quantity effect, measures the variation that would be caused by changes in the composition of imports if

${ }^{4}$ The uniform tariff is the tariff equal for every good that produces the same welfare loss as the actual structure (Corden I97I).

5 A radical alternative has been suggested by Leamer (I988) and adopted by Estevadeordal (1997). They first estimate the difference between the actual trade and the 'ideal' level, predicted on the basis of the country's endowment of resources and the distance from its main trading countries. Then they assume that these differences were caused by barriers to trade. This inference is convenient but unfortunately unwarranted. In fact the differences also pick up the effects of deviations from the assumptions of the HeckscherOhlin trade model (perfect competition, no economies of scale etc.) and all the measurement errors. As Pritchett (1996) shows, the measure is poorly correlated with other indices of openness. 
duties and prices remained constant. The third, or price effect, computes the change which would be caused by changes in prices. ${ }^{6}$

\section{What do we know about Italian protection?}

Italian trade policy after unification of the country (I86I) closely resembles that of other major European countries (Corbino 1931-5, Pedone 1969, Foreman-Peck 1994, Zamagni 1994, Bairoch 1976). The new Kingdom wholeheartedly joined the Europe-wide trade liberalisation movement, as the driving political force of the Risorgimento, Cavour's Piedmont, also happened to be the most liberal among Italian states at that time (together with Tuscany). Its tariff was immediately extended to the whole country (including the previously highly protected South) and two years later the remaining duties were abolished in a trade treaty with France. This freetrade policy officially lasted until the approval of a tariff in 1878 . This move pre-dated by one year the German tariff, which is usually regarded as the turning point towards the return to protection in Europe. The Italian protection was much strengthened in 1887 by the approval of a duty on wheat and of a new tariff on manufactures, which triggered a disastrous trade war with France, then Italy's main trading partner. The 1887 tariff lasted officially more than thirty years, but in the meanwhile many duties were changed by ad hoc laws and by trade treaties (notably those with Germany, Switzerland and Austria-Hungary in the early 1900s). A new comprehensive tariff on manufactures was approved by royal decree in I92I, to be reduced in 1923 by parliament and later by trade treaties with several European countries. The tide turned in 1925-6. First the government reinstated the duty on wheat (suspended since 1915) and then it raised duties on several goods. Predictably, the Great Crisis greatly speeded up the movement towards high protection. From the early I930s the Fascist government pursued an 'autarchic' policy, which relied more on quotas, clearing agreements and exchange rate controls than on tariffs.

On the basis of these facts, it is widely assumed that Italy was a free-trade country in the first twenty years after unification, that it switched to protectionism after 1878 (or possibly 1887 ), and that protection lasted until after World War II. And on the whole Italy's trade policy has the reputation of having been quite restrictive, so that the liberalisation of trade in the r 950 s has been hailed as a great break with its past history. A look at the yearly movement of the total NT (Figure I) only partially confirms this conventional wisdom. Protection did increase quite sharply from the late 1870 s to the early I890s, but the starting point, in spite of the official commitments, was already far from pure free trade. Besides, the level of protection had

${ }^{6}$ A similar analysis has been used by Crucini (1994). However, his approach is less accurate insofar as it takes into account the duty and price effects only. 


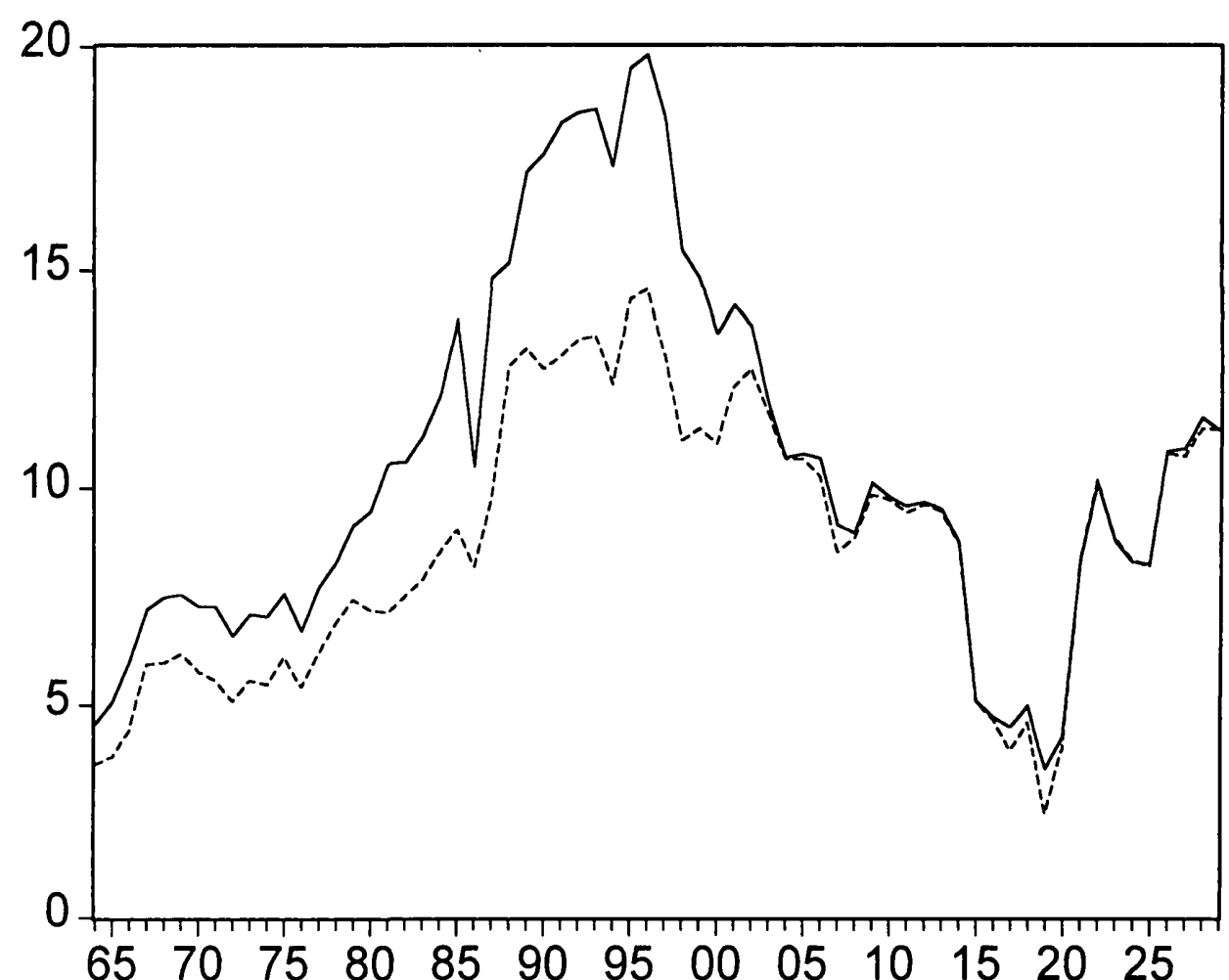

$$
\text { - NT ---- NT (excl. sugar) }
$$

Figure I. Nominal protection in Italy.

been falling since the late I890s, as quickly as it had risen before. The level of protection hit an historical low during World War I and rose afterwards. It was only at the end of the I920s that it exceeded decidedly the level of the ante-bellum years, well below the peaks of the early I890s. In other words, as a first approximation, one could argue that 'high' protection was a temporary, not a structural, feature of Italian development.

The potential shortcomings of the aggregate NT make necessary a more detailed analysis. In theory, one would like to compute all the measures listed above for every year. Such a task would be much too data-intensive, and therefore the research concerns five benchmark years only (1877, 1889, 1897,1913 and 1926) which seem fairly representative of the main phases in Italian trade policy. 1877 and 1889 straddle the phase of change in regime. ${ }^{7}$ The year 1897 marked the trough of world prices and at the same time the beginning of the first period of unmistakably fast growth in Italy. 1913 is the

7 The choice of years so close to the tariff changes has its disadvantages. It is possible that in both years, imports of protected goods were higher than 'normal' - in 1877 because of the expectations on the incoming tariff and in 1889 by lock-in effects. 
obvious choice for comparative purposes. Finally, 1926 is a (hopefully) representative compromise between the 'liberal' early I920s and the subsequent return to protection.

All the data on prices, quantities and specific duties are taken from the official collection of Italian trade statistics (Ministero delle Finanze, yearly). The number of items considered in the source grew from a few hundred in I877 to nearly 2,500 in 1926 . Therefore, they have been pooled together in 400 3- and 4-digit SITC aggregates (henceforth 'products'), which have been used for all the computations. This procedure yields a comparable data set, but unfortunately it entails the loss of some relevant information (notably for manufactures). The Italian trade statistics are sufficiently reliable. They might slightly overvalue prices and hence undervalue the nominal protection. The error is however small - in the region of 10-15 per cent at worst. ${ }^{8}$

The results are reported in Table AI of the Appendix. They show that NT in I877 was rather high mainly because of the duties on a small group of products, such as sugar, oil and coffee, which had been imposed in order to raise money for the state (Marongiu 1995, Parravicini 1958). ${ }^{9}$ Without them, the aggregate NT in 1877 would have been a mere 3.5 per cent. From then to I897 protection increased substantially, and this increase was entirely caused by the duty effect (Table A2), which includes in $1877-89$ the (small) effect of the trade war with France. ${ }^{10}$ The price effect was negligible, and the quantity effect was predictably negative (the composition of imports shifted away from the most protected goods). The implicit short-run elasticity is about $0.2-0.3$, assuming (with no firm evidence) that the demand curve did not shift and/or the relative prices of importables remained steady. In other words, as stated by the conventional wisdom, trade policy did cause the increase in aggregate protection. But, contrary to the conventional wisdom, the 1887 tariff and even the duty on wheat were not mainly responsible. Their contribution to the overall increase is measured (roughly) in Table I as the difference between the actual NT (Appendix Table AI) and a counterfactual NT computed on the assumption that the duties on each item (and the underlying demand curve) had remained constant.

${ }^{8}$ For more details see Federico and Tena 1998 and, on the reliability of Italian statistics, Tena 1989 and Federico and Tena I99I.

9 These duties are commonly referred to as 'fiscal' ones in opposition to the usual 'protective' ones. We will retain this convention, even if the precise definition of 'fiscal' duty is quite tricky. As shown in the recent debate between Nye (1993) and Irwin (1993), it depends largely on the elasticities of consumption.

${ }^{10}$ The extra duties on French goods (50 per cent on top of the 'normal' tariff, without the most favoured nation clause) accounted for about 0.6 percentage points of the NT in I889. The figure is obtained by multiplying the extra duty by the French share of total imports ( 12 per cent), on the assumption that the commodity composition was the same. Of course, the real effect on trade may have been larger, as the extra duty caused imports to shrink - but it cannot be easily estimated. 
Table I. Contribution to the increase in overall protection (NT).

\begin{tabular}{lll}
\hline \hline From I877 to: & I889 & I897 \\
\hline Sugar & 3.8 & 5.1 \\
Wheat & 2.6 & 2.3 \\
Manufactures & 2.8 & 2.1 \\
Sugar, oil, coffee & 6.3 & 8.5 \\
Wheat and manufactures & 5.4 & 4.4 \\
\hline \hline
\end{tabular}

Sources: See text.

The increase in the duty on sugar alone (from 28 per cent in 1877 to a staggering 314 per cent in 1897) caused protection to grow more than either the tariff on manufactures or the duty on wheat. As the dotted line in Figure I shows, without sugar the peak in protection in the late I880s and I89os would have been much less steep. And the combined effect of 'fiscal' duties on sugar, oil and coffee was larger than that of the duty on wheat and on manufactures together.

The duty effect accounted for about two thirds of the decrease in protection from the peak of 1897 to I9I3 (Table A2, Appendix). Again, the fall was caused mainly by the cuts in fiscal duties, while the protection on other goods stayed constant or increased slightly. The rest of the fall in protection is accounted for by the price effect, which was caused by the growth in world prices (by 23 per cent according to Lewis's estimate (Lewis I98I)). As expected, the quantity effect was positive, roughly with the same implicit elasticity as before (about $0.2-0.3$ ).

The modest rise in aggregate NT from 1913 to 1926 is the balance between a positive duty effect and a negative price effect. ${ }^{\text {II }}$ The former is accounted for mainly by the increase in duties on manufactures brought about by the I $92 \mathrm{I}-23$ tariff. The fiscal duties on sugar, coffee and oil were actually lower than in 1913, and the duty on wheat was roughly the same. If imports of wheat had remained free as they had until 1925, the aggregate duty in 1926 would have been 8.20 only - i.e. slightly below the 1913 level.

So far, the discussion has relied on the (import-weighted) NT measure, which, as discussed before, may bias the results downwards. How serious is the problem? Not too severe, if we trust a comparison with other measures. The lack of suitably detailed data prevents the computation of the consumption-weighted index (NTWz) and of the output-weighted index (NTWw) in

"The price effect has been computed by excluding the official adjustment for inflation.

The duties of the I92 I tariff were officially expressed in 1913 (gold) lire, and the customs revenues were collected multiplying them by a coefficient equal to the depreciation of the lira. The coefficient was revised fortnightly. The average for 1926 was $5.0-$ implying that prices were 0.20 times those of 1913 . 
any year but $1913 .{ }^{12}$ In that year NTWW (II.76) was indeed higher than NT, but not substantially so. Besides, as argued before, the figure is an upper bound of the true value, as the index overvalues the level of protection. It is possible to compute the other trade-based measures, such as RNT (weighted with base-year quantities) and UNT (simple averages). Table 2 reports the results.

All the figures are not far from one and this is reassuring evidence of the robustness of NT. In three years out of five, UNT - for both total trade col. (a) and dutiable goods col. (b) - turns out to be lower than NT. As column (c) shows, until 1897 the ratio was high because imports of sugar were very substantial (accounting for about 2 per cent of the total until the early I900s) in spite of the very high duty. The results on the NT/RNT ratio are mildly puzzling. Ceteris paribus, one would expect the ratio to be below unity if protection was rising (as in Italy from I877 to 1897) and above it if protection was falling (as from I897 to I913). The difference would be the larger, the more elastic is demand. In the Italian case, the RNT is always higher than NT, and this contradicts our a priori expectations for I9I3. One could hypothesise that the ceteris paribus clause did not hold - i.e. that the demand structure had changed for reasons other than protection.

Finally, Table $\mathrm{A}_{3}$ of the Appendix reports the estimates of TRI (the trade restrictiveness index). They have been computed under the (questionable) assumption that the elasticities of substitution and transformation were the same for all products, but with a wide range of values. As mentioned earlier,

Table 2. Comparison of different measures of nominal protection.

\begin{tabular}{lllll}
\hline \hline & $\begin{array}{l}\text { NT/UNT } \\
\text { (a) }\end{array}$ & $\begin{array}{l}\text { NT/UNT } \\
\text { (b) }\end{array}$ & $\begin{array}{l}\text { NT/UNT } \\
\text { (c) }\end{array}$ & $\begin{array}{l}\text { NT/RNT } \\
\text { (a) }\end{array}$ \\
\hline I877 & I.07 & I.12 & 0.73 & n.a. \\
I889 & 1.04 & I.15 & 0.64 & 0.86 \\
1897 & 1.15 & 1.29 & 0.69 & 0.89 \\
1913 & 0.75 & 0.75 & 0.64 & 0.82 \\
1926 & 0.87 & 0.74 & 0.68 & 0.79 \\
\hline \hline
\end{tabular}

Note: (a) total trade; (b) trade in dutiable goods only; (c) total trade without sugar.

Source: Appendix Table Ar.

12 The computation is based on the estimates of value added in I9II by Federico (1992) and Fenoaltea (1992). Unfortunately, the need to match those data with the foreign trade SITC classification seriously restricts the scope for the computation. It has to be based on 105 'products', 38 of which consist of foodstuffs. The groups for manufacturing are rather large and, in some cases, hardly homogeneous. For instance, 'engineering' includes all types of machinery and 'wood products', being estimated from incomes, does not distinguish grossly sawn wood from furniture. 
TRI measures the percentage change in the uniform tariff - either from one benchmark year to another (Table A3a) or from the actual tariff to a (hypothetical) free trade regime (Table $\mathrm{A}_{3} \mathrm{~b}$ ). These latter figures (the absolute values of TRI) are by definition negative, and they are the higher the more protected the economy was.

The peculiar features of Italian trade policy - above all the wide changes in duties on a small group of goods (sugar again) make the estimation of changes in TRI quite difficult. In some cases, the system does not converge for plausible values of the parameters, and the relevant figures have been omitted from Table A3a). This is the case for $1877-89$. A rough estimate would suggest positive values of TRI, in the range $1.20-1.40 .^{13}$ In other cases, the sign of TRI depends on the assumed elasticities - such as from I889 to 1897 and from I9I3 to I926. This latter result is not too disturbing, as the changes are anyway very small. By contrast, TRI confirms unequivocally the extent of the trade liberalisation from I897 to I913. The 'free-trade' computation (Table A3b) yields better results - and the implicit ranking of the figures is consistent with the previous analysis of NT. Protection turns out to have been much higher in 1897 and I889 than at any other time. Interestingly, the figure for 1913 (allegedly a 'protectionist year') is decidedly lower than that for 1926 or even 1877 .

Though questionable one by one, all the measures discussed in the previous sections tell a similar story. Protection started from a quite low level, increased in the I880s and early I890s, then fell in the I900s and remained roughly constant until the late I920s. How did these movements affect Italian economic growth?

\section{On protection, welfare and economic growth}

Protection reduces welfare, as it causes a misallocation of resources. However, the short-run welfare losses seems to have been on the whole modest - at least with a fixed endowment of resources. As is well known, the dead-weight losses can be measured as a first approximation by the size of the Haberger triangles, which can be estimated as a share of GNP, with the formula (Vousden 1990, p. 49):

$$
\text { DWL/GNP }=0.5 a^{2} \beta n
$$

where $a$ is the fall in prices that would be caused by the abolition of the tariff (and which for non-prohibitive duties can be proxied by NT/(I $+N T), \beta$ is the import/GNP ratio and $n$ the compensated (own) price elasticity of

\footnotetext{
${ }^{13}$ These figures are obtained by extrapolating from a regression for the results obtained with elasticities ranging from 20 to 50 , and then adjusting the results according to those of a similar regression for $1913-26$.
} 
Table 3. Estimates of welfare losses (per cent of GDP).

\begin{tabular}{llll}
\hline \hline Elasticity & $n=-\mathrm{I}$ & $n=-4$ & $n=-8$ \\
\hline I877 & 0.03 & $0.1 \mathrm{I}$ & $0.2 \mathrm{I}$ \\
I889 & 0.17 & 0.68 & 1.35 \\
I897 & 0.15 & 0.60 & 1.20 \\
I9I3 & 0.07 & 0.30 & 0.59 \\
I926 & 0.10 & 0.38 & 0.76 \\
\hline \hline
\end{tabular}

Sources: See text.

demand for imports. This latter is as yet unknown, so the losses are estimated with a broad range of values (Table 3 ).

The computation is biased downward as it does not take into account the indirect effects on input allocation and returns, which can be properly estimated only with a CGE model. But the figures are so small, even under the totally implausible assumption of an elasticity as high as -8 , that substantial losses are extremely unlikely. This result is consistent with most research on protection, which almost always shows that total losses of GDP are negligible in comparison with changes in distribution.

Besides, the welfare losses caused by the increase in protection were to some extent balanced by the fall in the dispersion of duties. In fact, ceteris paribus (i.e. for any given average level of protection), the distortions in resource allocation are proportional to the dispersion of the tariff (Corder. I97I). In I877 Italian protection was very skewed towards a few goods, so that the simple coefficient of variation was as high as 2.5 (Appendix Table AI). The approval of tariffs caused dispersion to fall, and the coefficient halved to 1.2 on the eve of World War I. Afterwards, the fall stopped, and in I926 the level of dispersion was as great as fifteen years before.

This welfare argument discussion so far would seem rather pointless to a 19th century protectionist and perhaps also to an historian $\dot{a}$ la Bairoch. They would argue that even very substantial losses were a price worth paying for fostering industrialisation in the long-run. This reasoning shifts the focus from the overall level to the structure of protection, and especially to the levels granted to manufacturing relative to competing activities. To be sure, the relation between the growth of gross output and protection is not necessarily linear as often assumed (Anderson 1994). Yet, a minimal prerequisite of an effective tariff-based strategy for industrialisation seems to be that manufacturing was more protected than agriculture. This was not always the case in 19th century Italy, at least for manufacturing as a whole. Nominal protection on industrial products (including semi-manufactured goods) was higher than on primary products in 1889 and 1926 , similar in I 877 and 1913 and much lower in 1897 (Appendix Table AI). This result 
should not really be surprising, as the primary products include sugar, oil, coffee and wheat. However, trade policy towards manufacturing was a bit more consistent than overall trade policy. The duty effect was always positive, and quite high both in 1877-89 and 1913-26 (Appendix Table A2). NT on industrial products did not grow accordingly because the price and quantity effects were consistently negative throughout the period. The quantity effect was particularly large in 1889-97 and this may be evidence of successful import substitution. Though likely, this inference is not certain.

Such an aggregate approach is questionable. One could argue that large categories such as manufactures or primary products are not representative. After all, the infant industry argument suggests supporting each industry just for the (hopefully short) time it needs to grow enough to stand up to world competition, not the whole of manufacturing forever. Indeed, the whole debate on trade policy and development in Italy and in Europe deals much more with the choice of protected activities than with the wisdom of protectionism as a strategic choice. Historians have focused on a rather narrow set of products - wheat, steel products, cotton manufactures and machinery (Federico I994). Gerschenkron (I962) criticised all these choices. He deemed the duty on wheat harmful to industrialisation as it unnecessarily increased the price of a basic wage good, the protection on cotton pointless as it was an 'old industry with limited possibility of technical progress', and that on iron and steel positively harmful because of its perverse effects on the engineering industry. Fenoaitea has elaborated these criticisms in a more explicitly counterfactual framework. First he has argued that without the duty on its inputs Italian engineering could have started export-led growth from the late I9th century (Fenoaltea I973). ${ }^{14}$ More recently (Fenoaltea I993) has blamed the increase in nominal wages caused by the duty on wheat for having curtailed the potential growth in industrial employment, and hence for having stimulated emigration.

Table 4 reports estimates of the effective protection rates for these products as ratios to the all-produce average rate of protection. ${ }^{15} \mathrm{By}$ and large, they confirm the conventional wisdom. Sugar stands out for the level of protection it was granted, but about two thirds of the rents were taken away from domestic producers by a high excise tax. Wheat-growing was protected by more than the average after 1887 - and this affected agriculture

${ }^{14}$ Toniolo (1977) has estimated that subsidizing iron and steel production instead of protecting it would have increased overall GDP at most by I.5 per cent in $1906-8$. He does not consider free trade as a counterfactual.

${ }^{15}$ The figures are the simple averages of three estimates, with different input-output tables (referring to Italy in I9I I, Italy in 1950 and the United Kingdom in 1907). As none of these tables is really suitable, we have opted for the simplest Balassa formula $\mathrm{EP}_{i}=\left[\mathrm{T}_{i}-\right.$ $\left.\sum a_{i j} T_{j}\right] /\left[\mathrm{I}-\sum a_{i j}\right.$, where $i$ refers to the product, $j$ to the input, $\mathrm{T}$ is the nominal duty, and $a_{i j}$ are the technical coefficients of the input-output table. The overall effective protection is computed as a trade-weighted average of the rates on each product. For more details on the computation see Federico and Tena 1998. 
Table 4. Ratio of effective protection on selected goods to the average.

\begin{tabular}{lrrrrr}
\hline \hline & I877 & I889 & I897 & I913 & 1926 \\
\hline Sugar & 4.1 & I7.5 & 24.4 & I3.2 & 3.0 \\
Iron and steel & I.6 & 2.0 & 2.8 & 3.9 & 3.5 \\
Grain & 0.5 & 1.6 & 2.5 & 2.6 & I.5 \\
Cotton textiles & 2.7 & 3.7 & 3.6 & 2.3 & 0.9 \\
Wool textiles & $-\mathrm{I} .3$ & 2.1 & 2.9 & $\mathrm{I} .8$ & 2.2 \\
Chemicals & 0.0 & -0.1 & -0.2 & I.I & I.9 \\
Machinery & 0.1 & 0.3 & 0.3 & 0.5 & I.3 \\
\hline \hline
\end{tabular}

Source: Federico and Tena 1997.

much more than the protection on production of sugar-beet, which accounted for a mere 0.5 per cent of Gross Saleable Production in I9I I (Federico I992 Table IA). The iron and steel industry has always been relatively protected, as it was considered essential for military purposes. Cotton was protected more than wool, its nearest competitor among textiles, until the I890s, but afterwards became a net exporter in a fiercely competitive world market. The engineering industry was undoubtedly hit by the duties on steel, even if technically protection was not negative as sometimes stated. From this point of view another 'modern' industry of the Second Industrial Revolution, the chemical industry, fared decidedly worse until the $1921-23$ tariff. A look at the whole structure of protection casts some doubts on the relevance of protection for industrialisation. Before 1926, very few manufactures (mainly steel goods, but also some chemical products) appear in the list of the ten or twenty most protected goods and only sugar made it to the top in 1897 . The list is a surprising collection of seemingly unrelated products, including, inter alia, tobacco, manufactured wines and, more interestingly, crude or refined oils and coffee. None of these products had a clear domestic substitute (firewood? hot milk?), and hence duties were purely 'fiscal' ones.

The analyis of the relative levels of protection highlights the complexity of the design of Italian trade policy, which sometimes bordered on the haphazard. In the companion paper (Federico and Tena 1998) we argue that it was shaped more by the need for revenue than by a deliberate policy to foster industrialisation, by sectional interests or by international relations. Proving this hypothesis, however, entails a different research agenda.

\section{What can we learn from the Italian case?}

Summing up, aggregate protection in Italy seems to have been rather low, except for a short period in the I89os. It was neither very harmful to welfare, nor did it contribute to industrialisation as a whole. At best, the trade policy might have helped some industries (notably steel) against others. But these 
Table 5. Spearman correlation coefficients among different estimates of protection.

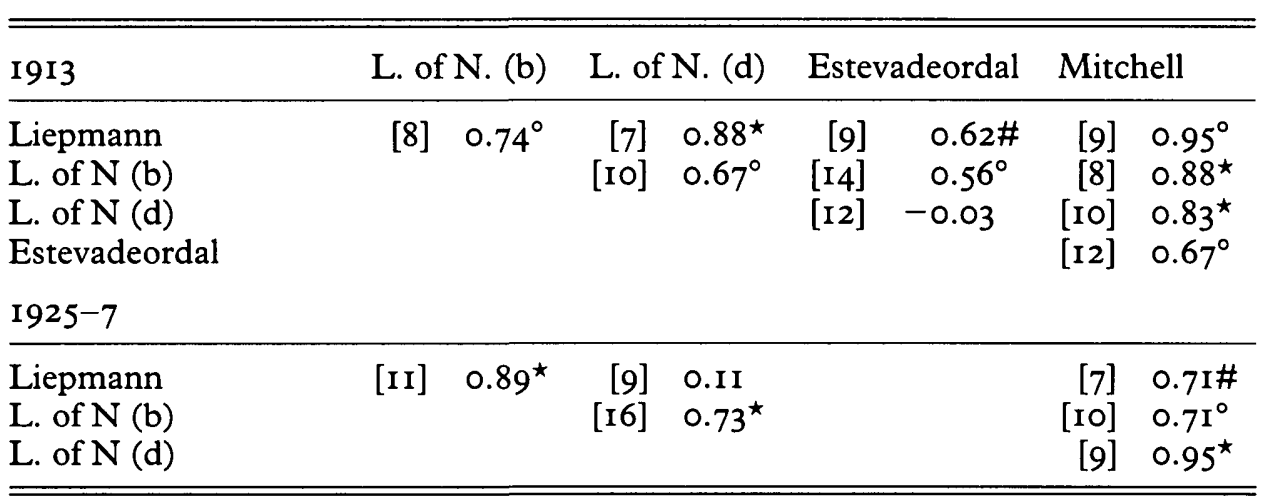

Notes: Significantly different from zero at ${ }^{\star} \mathrm{I} \%,{ }^{\circ} 5 \%$, \#10\%; number of countries in square brackets.

Source: Appendix Tables A4 and A5.

were exceptions, and anyway they were less protected than some primary products.

Of course, strictly speaking, these conclusions are valid for Italy only and do not prove, beyond any reasonable doubt, that protection was not important in other European countries. Such a strong statement should be supported by a quantitative analysis as detailed as this one. It is, however, possible to collect some evidence, albeit far from theoretically optimal. Table A4 of the Appendix reports NT for our benchmark years computed from the annual series of custom revenues and imports (mainly from Mitchell 1975). Table A5 adds some other figures for 1913 and the I920s from different sources, and the recent estimates by Estevadeordal (I997) of Leamer's (1988) trade distortion index. Some of these figures (notably Mitchell's) are questionable,${ }^{16}$ and they are all not directly comparable, as they use different measures. In spite of these differences, the country ranking is fairly similar (Table 5), with the partial exception of Estevadeordal.

As Table 6 shows, Italy almost always ranks consistently in the middle of the sample. Does this mean that Italy was some sort of a 'median' country? The conclusion may seem a little too bold. First, it contrasts with Estevadeordal's estimates, which however in the case of Italy are rather

\footnotetext{
${ }^{16}$ At least the data for Italy are seriously flawed. The estimate for 1926 does not adjust for the difference between gold and paper-lire (see footnote II), and therefore the estimate has been omitted from the table. Besides, the data on customs revenues are seriously flawed, as they always omit the duty on wheat, as stated by Mitchell's original source (ISTAT 1958, p. 22), and from 1885 onwards they refer to fiscal year instead of calendar year, and therefore are not homogeneous with the trade statistics.
} 
Table 6. Italy's position according to different estimates of nominal protection.

\begin{tabular}{lll}
\hline \hline & I913 & 1925-7 \\
\hline Mitchell & 7 out of I4 & na \\
L. of N (b) & 7 out of 16 & 9 out of 20 \\
L. of N (d) & 6 out of I3 & 8 out of 16 \\
Liepmann & 6 out of I3 & 9 out of 15 \\
Estevadeordal & 2 out of I8 & na \\
\hline \hline
\end{tabular}

Source: Appendix Table A5.

puzzling. ${ }^{17}$ Moreover, the sample includes many small countries, which would be difficult to compare with Italy. But the differences with 'similar' countries such as France and Germany were not that large. Italy was more protected than Germany and France in the I920s but not in 1913 (Tena 1992). And at any time protection in Europe was much lower than in the United States.

The similarities extend to the structure of protection. The best available evidence is provided by Liepmann's estimates of nominal protection in 1913 and 1927 (Table 7). The data seem to rule out the view that trade policy favoured industry over other activities. This European pattern contrasts with the American one, which levied duties on manufactures only. The need for revenue seems to loom large as a cause of protection in France and Germany as well. Customs revenues accounted for a sizeable share of total revenues (Bairoch 1989, Table 8) and in real terms they increased after the return to protection, even more than in Italy (Figure 2). This result was achieved also thanks to quite high duties on high-demand low-elasticity goods, such as mineral oils, alcohol and tobacco. The trade policy of European countries in the decades before World War I may have resembled more that of Britain in the 1840s-70s (Nye I99I) than the importsubstitution strategies of the LDCs in the I950s-60s.

\footnotetext{
${ }^{17}$ The ranking for overall protection (Estevadeordal 1997, Table 6) does not tally with the product-level data of Table 7. Italy ranks second overall, but is fourth for raw materials (which included petroleum), fifth for processed agricultural products (which included sugar), sixth for cereals and textile fibres and between seventh and fifteenth for manufactures. Besides, Italy's low level of trade (which in Estevadeordal's framework reflects barriers to trade) is accounted for by wood products, cereals, other vegetable and animal products, dairy products, fish and coal (Table I0). Of all these commodities, only cereals were protected at all. Apart from repeating the author's caveats on the reliability of the data (especially those on resource endowments and on the assumptions of same tastes, technologies etc.), one can only speculate on the causes of these differences. A candidate may be Italy's high trade deficit (equivalent to 3 I.5 per cent of total imports) which conflicts with the assumption of balanced trade. One may be reminded that Leamer (1988) included the trade balance among the explanatory variables.
} 
Table 7. Nominal duties by broad categories of goods.

\begin{tabular}{|c|c|c|c|c|c|}
\hline & & $\begin{array}{l}\text { 'Fiscal' } \\
\text { goods" }\end{array}$ & $\begin{array}{l}\text { Food- } \\
\text { stuffs }\end{array}$ & $\begin{array}{l}\text { Semi- } \\
\text { manufactures }\end{array}$ & $\begin{array}{l}\text { Manu- } \\
\text { factures }\end{array}$ \\
\hline \multirow[t]{2}{*}{ France } & I9I3 & 72.3 & 21.0 & I6.4 & I2.9 \\
\hline & 1927 & 30.9 & I 2.7 & 12.0 & 21.6 \\
\hline \multirow[t]{2}{*}{ Germany } & 1913 & 35.7 & I 8.8 & I3.2 & 8.5 \\
\hline & 1927 & 51.0 & I9.6 & 10.4 & 15.5 \\
\hline \multirow[t]{2}{*}{ Italy } & 1913 & 82.3 & I7.I & $2 \mathrm{I} .4$ & I 2.6 \\
\hline & 1927 & 6I.I & I 5.8 & 22.2 & 22.2 \\
\hline
\end{tabular}

Notes: * Alcoholic drinks, tobacco, mineral oils and 'other foodstuffs' (colonial goods and sugar).

Source: Liepmann 1938, first column Table AI ('potential tariffs') pp. 383, 385, 386 and 400.

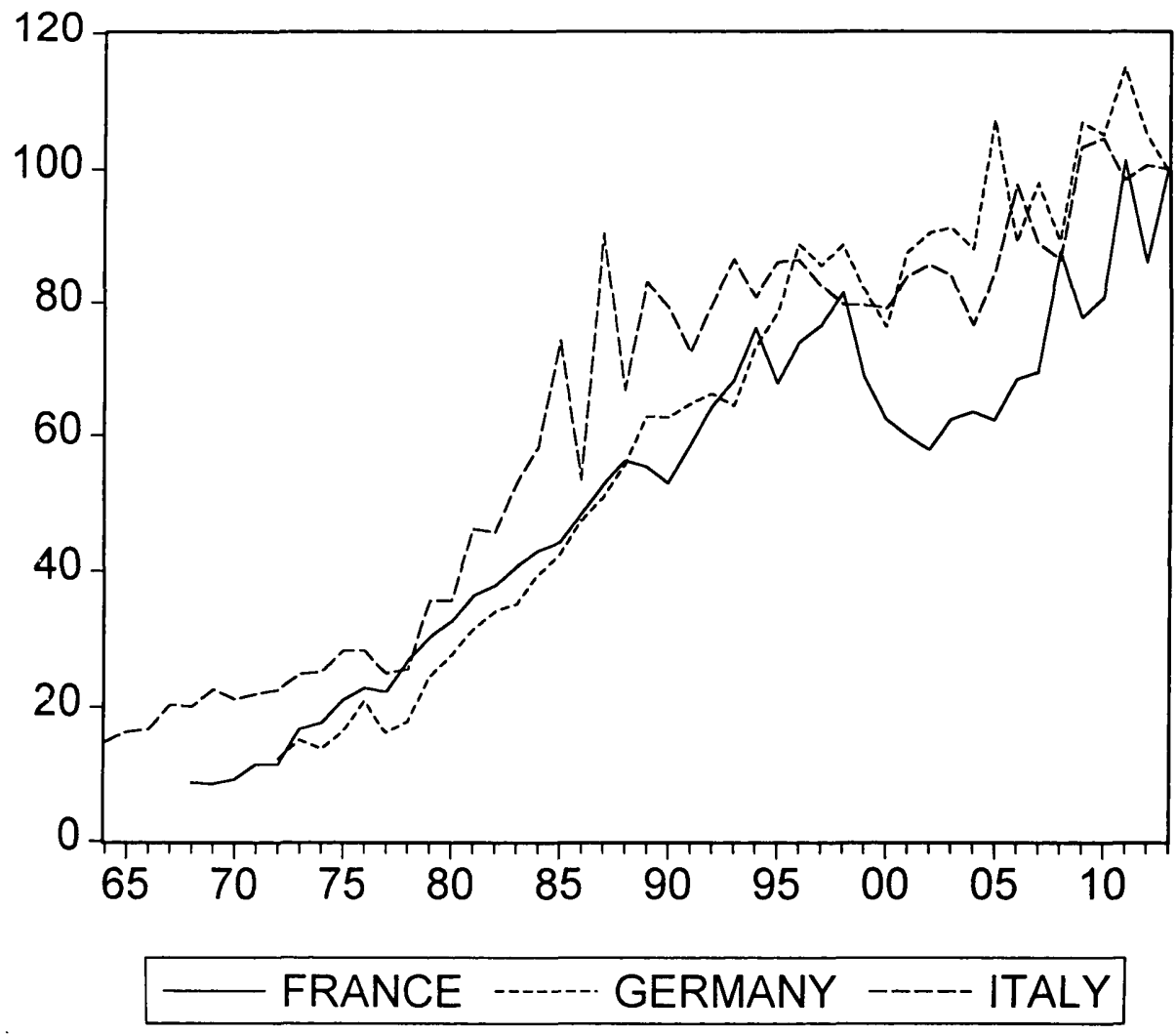

Figure 2. Real customs revenue $(1913=100)$.

On the basis of this evidence, one might conclude that Capie was right. Protection in the major European countries was low and did not favour 
industry. Therefore trade policy was not likely to have played such a paramount role in industrialisation. However, this conclusion relies on the assumption that the traditional measures of protection such as NT are not too biased. We have previously shown that this was the case for Italy, but this is an empirical finding, and the same exercise should be replicated for other countries.

\section{Acknowledgements}

Previous versions of this paper have been presented in seminars at the EUI (Florence), the Universidad Carlos III (Madrid), the London School of Economics, the Universities of Oxford and Strathclyde (Glasgow), at a seminar organised by the European Review of Economic History in Copenhagen (November 1996) and at the Third World Congress of Cliometrics in Munich (July 1997). The authors wish to thank all the participants at these venues, F. Capie, S. Fenoaltea, G. Toniolo and V. Zamagni for their useful comments, and J. Anderson for having provided the spreadsheet to compute the TRI. The companion paper is available on request. The authors wish to thank the Spanish Ministry of Education (Grant CGYCITPB 9/0373) and the Italian MURST (Funding 60\%) for financially supporting the research.

\section{References}

Anderson, J. (1994). The theory of protection. In D. Greenaway and L. A. Winters (eds), Surveys in International Trade, pp. 107-38. Oxford: Basil Blackwell. ANDERSON, J. (1995). Tariff-index theory. Review of International Economics 3, pp. 156-73.

Anderson, J. and Neary, J. P. (1994). Measuring the restrictiveness of trade policy. World Bank Economic Review 8, pp. I7I-89.

Anderson, J. and Neary, J. P. (1996). A new approach to evaluating trade policy. Review of Economic Studies 63, pp. 107-25.

Balassa, B. (1965). Tariff protection in industrial countries. An evaluation. Fournal of Political Economy 73, pp. 573-94.

BAIRoch, P. (1976). Commerce Exterieur et Developpement Économique de l'Europe au $X I X$ siècle, Paris-Le Haye: Mouton.

Bairoch, P. (1989). European trade policy 1815-1915. In P. Mathias and S. Pollard (eds), The Cambridge Economic History of Europe 8, pp. I-60. Cambridge: Cambridge University Press.

BAIroch, P. (1996). Economics and World History. Brighton: Harvester Wheatsheaf. BOARD OF TRADE (1905). The comparative incidence of foreign and colonial import tariffs on the principal classes of manufactures exported from United Kingdom. British Parliamentary Papers 84, pp. 280-320.

CAPIE, F. (1983). Tariff protection and economic performance in the nineteenth century. In J. Black and L. A. Winters (eds), Policy and Performance in International Trade, pp. I-24. London: Macmillan.

CAPIE, F. (1994). Tariffs and Growth. Some Illustrations from the World Economy I850-1914. Manchester: Manchester University Press. 
Corbino, E. (1931-35). Annali dell'Economia Italiana, 5 volumes. Leonardo Città di Castello.

CoRden, M. (197I). The Theory of Protection. Oxford: Oxford University Press. CRUCINI, M. J. (1994). Sources of variation in real tariff rates: the United States 1900-1940. American Economic Review 84, pp. 732-43.

ESTEVADEORDAL, A. (1997). Measuring protection in the early twentieth century. European Review of Economic History I, pp. 89-125.

Federico, G. (I992). Il valore aggiunto dell'agricoltura. In G. Rey (ed.), I Conti Economici dell'Italia 2: Una Stima del Valore Aggiunto per Rami di Attività per il I9II, pp. 3-103. Bari: Laterza.

Federico, G. (1994). Introduction. In G. Federico (ed.), The Economic Development of Italy. Aldershot: Elgar.

Federico, G. and TenA, A. (I99I). On the accuracy of foreign trade statistics (1909-13): Morgerstern revisited. Explorations in Economic History 28, pp. 259-73. Federico, G. and Tena, A. (1998). Did trade policy foster industrialisation? An analysis of effective protection in Italy, $1870-1930$. Mimeo.

FeENSTRA, R. C. (I995). Estimating the effects of trade policy. In G. Grossman and K. Rogoff (eds), Handbook of International Economics 3, pp. 1553-92.

Amsterdam: Elsevier North Holland.

FenoalteA, S. (1973). Riflessioni sull'esperienza industriale italiana dal

Risorgimento alla prima guerra mondiale. In G. Toniolo (ed.), Lo Sviluppo Economico Italiano 1861-1940. Bari: Laterza.

Fenoaltea, S. (1992). Il valore aggiunto dell'industria. In G. Rey (ed.), I Conti Economici dell'Italia 2: Una Stima del Valore Aggiunto per Rami di Attività per il IgII, pp. I05-90. Bari: Laterza.

Fenoaltea, S. (1993). Politica doganale, sviluppo industriale, emigrazione: verso una considerazione del dazio sul grano. Rivista di Storia Economica 10, pp. 65-77. Foreman-Peck, J. (1994). A History of the World Economy, 2nd edn. Brighton: Harvester Wheatsheaf.

Gerschenkron, A. (1962). Economic Backwardness in Historical Perspective. Harvard: Bellknap.

Greenaway, D. and Milner, C. (I993). Trade and Industrial Policy in Developing Countries. London: Macmillan.

ISTAT (1958). Sommario di Statistiche Storiche Italiane. Rome: ISTAT.

IRWIN, D. (1993). Free trade and protection in nineteenth century Britain and France revisited: a comment on Nye. Fournal of Economic History 53, pp. 146-52. League of Nations (1927). Tariff Levels Indices. Geneva: League of Nations. LeAmer, E. E. (1988). Measures of openness. In R. E. Baldwin (ed.) Trade Policy: Issues and Empirical Analysis, pp. 147-200. Chicago: University of Chicago Press. Levy-Leboyer, M. and Bourguignon, F. (1985). L'Economie Francaise au XIX siecle. Paris: Economica.

LEwIS, W. A. (198I). The rate of growth of world trade 1870-1913. In S.

Grassman and E. Lundberg (eds), The World Economic Order. Past and Prospects, pp. II-8I. London: Macmillan.

Liepmann, H. (1938). Tariff Levels and the Economic Unity of Europe, London:

Allen and Unwin.

Marongru, G. (I995). Storia del Fisco in Italia. Turin, Einaudi. 
MCCloskey, D. (1980). Magnanimous Albion: free trade and British national income, I84I-8I. Explorations in Economic History 17, pp. 303-20.

Minami, R. (1994). The Economic Development of fapan. London: Macmillan. Mrtchell, B. R. (1975). European Historical Statistics 1750-1970. London:

Macmillan.

Ministero delle Finanze (yearly). Direzione Generale delle Gabelle ed Imposte Indirette. Movimento Commerciale del Regno d'Italia. Roma-Firenze.

NYE, J. V. (I99I). The myth of free-trade Britain and fortress France: tariffs and trade in the XIXth century. Fournal of Economic History 5I, pp. 23-45.

NYE, J. V. (1993). Reply to Irwin on free trade. Fournal of Economic History 53, pp. I $53-58$.

O'Rourke, K. (1997). Measuring protection: a cautionary tale. Fournal of Development Economics 53, pp. 169-83.

Parravicini, G. (1958). La Politica Fiscale e le Entrate Effettive del Regno d'Italia 1860-90. Torino: ILTE.

Pollard, S. (1982). Peaceful Conquest. Oxford: Oxford University Press.

Pedone, A. (1969). La politica del commercio con l'estero. In G. Fuà (ed.), Lo

Sviluppo Economico in Italia 2, pp. 24I-59, Milano: Franco Angeli.

PritchetT, L. (1996). Measuring outward orientation in LDCs: can it be done?

Fournal of Development Economics 49, pp. 307-55.

SAPELLI, G. (I99I). Technical change, microeconomic evolution and growth: an introductory view of Italian economic development. In G. Dosi, R. Giannetti and P. A. Toninelli (eds), Technology and Enterprise in Historical Perspective, pp. 291-313. Oxford: Oxford University Press.

Tena, A. (1989). On the accuracy of Italian foreign trade statistics, I890-1938.

Rivista di Storia Economica 6, pp. 87-112.

TENA, A. (1992). Proteccion y competitividad en España et Italia, I890-1960. In L. Prados de la Escosura and V. Zamagni (eds), El Desarollo Económico en la Europa del Sur: España e Italia en Perspectiva Historica, pp. 32 I-57. Madrid: Alianza.

Tena, A. (1998). Proteccion y Crecimiento Econòmico en la España de la Restauraciòn 1870-1930. Mimeo.

TonioLo, G. (1977). Effective protection and industrial growth: the case of Italian engineering. Fournal of European Economic History 6, pp. 659-73.

TUMI.IR, J. and TILL, L. (I97I). Tariff averaging in international comparison. In H. G. Grubel and H. G. Johnson (eds), Effective Tariff Protection, pp. 147-59. Geneva: GATT.

US Department of Commerce, Bureau of the Census (1976). Historical Statistics of the United States. Washington: Government Printing Office.

Vousden, N. (1990). The Economics of Trade Protection. Cambridge: Cambridge University Press.

Zamagni, V. (1994). An Economic History of Italy. Oxford: Oxford University Press. 


\section{Appendix}

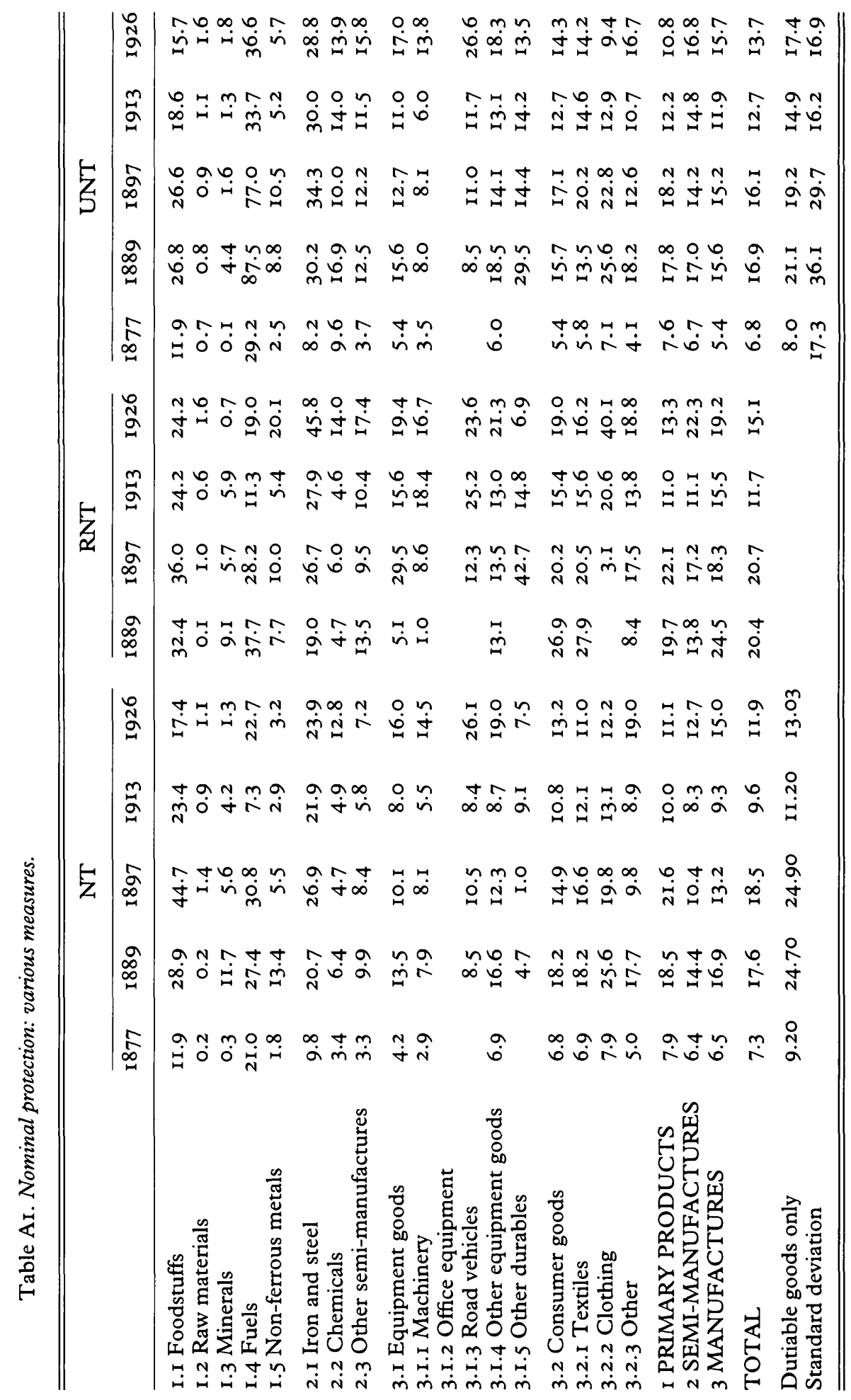


94 European Review of Economic History

Table A2. Decomposition of changes in nominal duties.

\begin{tabular}{|c|c|c|c|c|c|}
\hline & (a) & (b) & (c) & (d) & Total \\
\hline \multicolumn{6}{|l|}{ I877-89 } \\
\hline Quantity & -7.8 & -3.1 & -0.3 & -1.3 & -3.7 \\
\hline Price & 6.6 & 3.7 & -7.3 & -4.4 & 0.9 \\
\hline Duty & II. 8 & 7.4 & 17.9 & I5.I & I3.I \\
\hline Total & 10.6 & 8.0 & 10.4 & 9.4 & 10.3 \\
\hline \multicolumn{6}{|l|}{ I889-97 } \\
\hline Quantity & $-O . I$ & -8.6 & -3.8 & -7.0 & -2.2 \\
\hline Price & -0.4 & 1.9 & -1.3 & I. 3 & 0.0 \\
\hline Duty & 3.6 & 2.8 & I.4 & 1.9 & 3.1 \\
\hline Total & 3.1 & -4.0 & -3.7 & -3.8 & 0.9 \\
\hline \multicolumn{6}{|c|}{ 1897-1913 } \\
\hline Quantity & 2.7 & $-0 . I$ & 0.2 & 0.1 & 2.2 \\
\hline Price & -3.7 & -2.7 & -6.3 & -4.9 & $-4 \cdot 3$ \\
\hline Duty & -10.6 & 0.7 & 2.2 & I.7 & -6.8 \\
\hline Total & -11.6 & $-2 . I$ & -3.9 & $-3 . I$ & -8.9 \\
\hline \multicolumn{6}{|l|}{$1913-26$} \\
\hline Quantity & 1.2 & -4.2 & -0.5 & -1.9 & 0.3 \\
\hline Price & -3.3 & -5.4 & -3.7 & -3.9 & -3.5 \\
\hline Duty & $3 \cdot 3$ & 13.9 & 9.9 & 10.9 & 5.5 \\
\hline Total & I.I & $4 \cdot 3$ & 5.7 & 5.2 & 2.3 \\
\hline
\end{tabular}

Notes: (a) Primary products; (b) Semi-manufactures; (c) Manufactures; (d) Industrial goods. 
Table A3. TRI

\begin{tabular}{|c|c|c|c|c|c|}
\hline & \multicolumn{3}{|c|}{ Elasticities } & \multicolumn{2}{|c|}{ TRI } \\
\hline & \multicolumn{2}{|c|}{ Substitution } & \multirow[t]{2}{*}{ Transformation } & \multirow{2}{*}{$\begin{array}{l}\text { Absolute } \\
\text { value }\end{array}$} & \multirow{2}{*}{$\begin{array}{l}\text { Change } \\
(\%)\end{array}$} \\
\hline (a) Changes & $\begin{array}{l}\text { Final } \\
\text { demand } \\
\text { year }\end{array}$ & $\begin{array}{l}\text { Intermediate } \\
\text { demand }\end{array}$ & & & \\
\hline \multirow[t]{3}{*}{ I889-97 } & 7 & 0.7 & 7 & I.I53 & 15.3 \\
\hline & 8 & 0.7 & 8 & 0.977 & -2.3 \\
\hline & IO & 0.7 & IO & 0.773 & -22.7 \\
\hline \multirow[t]{4}{*}{ I897-I9I3 } & 1.5 & 0.7 & I.5 & 0.39 & -61.0 \\
\hline & 2 & 0.7 & 1.5 & 0.251 & -74.9 \\
\hline & 5 & 0.7 & 5 & 0.191 & -80.9 \\
\hline & IO & 0.7 & IO & 0.182 & $-8 \mathrm{I} .8$ \\
\hline \multirow[t]{4}{*}{$1913-26$} & 1.5 & 0.7 & 1.5 & I.OII & I.I \\
\hline & 2 & 0.7 & 1.5 & 1.008 & 0.8 \\
\hline & 5 & 0.7 & 5 & 0.994 & -0.6 \\
\hline & I0 & 0.7 & I0 & 0.98 & -2.0 \\
\hline
\end{tabular}

(b) Yearly values

\begin{tabular}{|c|c|c|c|c|c|}
\hline \multirow[t]{5}{*}{ I877 } & I. 5 & I & 1.5 & 0.788 & $-2 \mathrm{I} .2$ \\
\hline & 2 & 0.7 & 2 & $0.82 \mathrm{I}$ & -17.9 \\
\hline & 5 & 0.7 & 5 & 0.831 & - I6.9 \\
\hline & 8 & 0.7 & 8 & 0.804 & - I9.6 \\
\hline & IO & 0.7 & IO & 0.753 & -24.7 \\
\hline \multirow[t]{6}{*}{ I 889} & I. 5 & I & 1.5 & 0.485 & -51.5 \\
\hline & 1.5 & 0.7 & 1.5 & 0.411 & -58.9 \\
\hline & 2 & 0.7 & 2 & 0.512 & -48.8 \\
\hline & 5 & 0.7 & 5 & 0.429 & -57.1 \\
\hline & 7 & 0.7 & 7 & 0.392 & -60.8 \\
\hline & 10 & 0.7 & IO & 0.364 & -63.6 \\
\hline \multirow[t]{4}{*}{ I897 } & 2 & 0.7 & 2 & 0.205 & -79.5 \\
\hline & 5 & 0.7 & 5 & 0.136 & -86.4 \\
\hline & 7 & 0.7 & 7 & 0.127 & -87.3 \\
\hline & 10 & 0.7 & IO & 0.12 & -88 \\
\hline \multirow[t]{5}{*}{1913} & I. 5 & I & 1.5 & 0.907 & -9.3 \\
\hline & 1.5 & 0.7 & 1.5 & 0.899 & -IO.I \\
\hline & 2 & 0.7 & 2 & $0.89 \mathrm{I}$ & -10.9 \\
\hline & 5 & 0.7 & 5 & 0.837 & -16.3 \\
\hline & IO & 0.7 & IO & 0.754 & -24.6 \\
\hline \multirow[t]{4}{*}{1926} & 1.5 & 0.7 & 1.5 & 0.645 & -35.5 \\
\hline & 2 & 0.7 & 2 & 0.739 & $-26 . \mathrm{I}$ \\
\hline & 5 & 0.7 & 5 & 0.76 & -24 \\
\hline & IO & 0.7 & IO & 0.719 & $-28 . I$ \\
\hline
\end{tabular}


Table A4. Nominal protection: Mitchell's data.

\begin{tabular}{|c|c|c|c|c|c|}
\hline & I877 & I889 & I897 & I9I3 & 1926 \\
\hline USA (a) & 29.2 & 30.0 & 21.9 & 17.7 & 13.4 \\
\hline (b) & 42.9 & 45.5 & 42.4 & 40.1 & 38.8 \\
\hline (c) & 68.4 & 66.2 & $5 \mathrm{I} .2$ & 46.5 & 34.9 \\
\hline Germany & na & 8.7 & 9.4 & 6.3 & 5.9 \\
\hline Russia & 16.5 & 31.9 & 35.0 & 27.0 & na \\
\hline United Kingdom & 5.1 & 4.7 & 4.9 & 4.2 & 8.7 \\
\hline France $(\alpha)$ & $5 \cdot 3$ & 8.1 & 10.8 & 9.2 & 4.9 \\
\hline$(\gamma)$ & 6.6 & 8.6 & 10.6 & 8.8 & na \\
\hline Austria-Hungary & 0.9 & 6.6 & 7.7 & 7.0 & $7.7^{\star}$ \\
\hline Italy $(\alpha)$ & 9.0 & 14.8 & 16.9 & 7.4 & 2.6 \\
\hline$(\beta)$ & $7 \cdot 3$ & 17.6 & I 8.5 & 9.6 & II.9 \\
\hline Japan (a) & 4.0 & 2.5 & 2.5 & 10.0 & 6.5 \\
\hline (b) & 4.5 & 3.0 & 3.5 & 19.5 & 16.0 \\
\hline Spain $(\alpha)$ & 16.4 & 16.2 & II.O & 16.4 & 15.7 \\
\hline$(\beta)$ & 12.7 & II.O & I 4.6 & I4.9 & 16.0 \\
\hline Belgium & 1.3 & I.7 & 2.2 & I.4 & 3.1 \\
\hline Netherlands & 0.6 & 0.4 & 0.5 & 0.4 & 2.2 \\
\hline Sweden & 8.6 & II. 3 & II. 8 & 8.I & 8.4 \\
\hline Switzerland & na & 3.1 & 4.7 & 4.5 & 9.2 \\
\hline Denmark & na & na & 9.5 & 4.5 & 5.8 \\
\hline Portugal & $3 \mathrm{I} .2$ & 33.3 & 32.5 & 24.7 & I3.I \\
\hline Europe (a) ${ }^{\circ}$ & 9.2 & 12.0 & II.9 & 9.3 & 8.3 \\
\hline
\end{tabular}

Notes: Italy France and Spain: $(\alpha)$ Mitchell's data; $(\beta)$ this research; $(\gamma)$ estimated by Levy LeboyerBourguignon 1985 Table VI; USA and Japan: (a) total trade; (b) only dutiable goods; (c) percentage of dutiable goods in total trade. ${ }^{\star}$ Austria only; ${ }^{\circ}$ simple average.

Sources: Italy: Appendix Table AI; Spain: Tena 1998 Table 2; Japan: Minami 1994 Fig 7.5; USA:

Historical Statistics 1976 series U208-U2II; others Mitchell I975 Table FI and H5. 
Table A5. Nominal protection: other estimates.

\begin{tabular}{|c|c|c|c|c|c|c|c|}
\hline & \multicolumn{4}{|c|}{1913} & \multicolumn{3}{|c|}{ I925-27 } \\
\hline & Liepmann & $\begin{array}{l}\text { L. of N. } \\
\text { (b) }\end{array}$ & $\begin{array}{l}\text { L. of N. } \\
\text { (d) }\end{array}$ & $\begin{array}{l}\text { Esteva- } \\
\text { deordal }\end{array}$ & Liepmann & $\begin{array}{l}\text { L. of N. } \\
\text { (b) }\end{array}$ & $\begin{array}{l}\text { L. of } \mathrm{N} \text {. } \\
\text { (d) }\end{array}$ \\
\hline Netherlands & & 3 & & 4.0 & & 4 & \\
\hline UK & & 0 & 9.6 & 6.2 & & 4 & 5.7 \\
\hline Denmark & & 9 & 4.6 & 6.8 & & 6 & 4.0 \\
\hline Germany & 16.7 & 12 & 8.2 & 8.6 & 20.4 & 12 & 4.8 \\
\hline France & 23.6 & 18 & 8.8 & I 2.3 & 23.0 & 12 & 3.3 \\
\hline Italy & 24.8 & 17 & 9.6 & 17.5 & 27.8 & 17 & 8.3 \\
\hline Belgium & $\mathrm{I} 4.2$ & 6 & I. 6 & IO.I & II.O & 8 & 3.2 \\
\hline Switzerland & 10.5 & 7 & 4.5 & 9.6 & I6.8 & II & 8.2 \\
\hline Austria & 22.8 & I8 & & II.O & I 7.5 & 12 & 7.0 \\
\hline Hungary & & & & & 30.0 & 23 & II. 6 \\
\hline Czechoslovakia & & & & & 31.3 & 19 & 4.6 \\
\hline Sweden & 27.6 & I6 & 8.2 & 8.3 & 20.0 & 13 & 9.0 \\
\hline Finland & 35.0 & & & 10.6 & 31.8 & & \\
\hline Portugal & & & & 14.9 & 53.5 & 23 & \\
\hline Norway & & & & 10.8 & 42.3 & & \\
\hline Russia & 72.5 & & & & 67.5 & & \\
\hline Poland & & & & & 49.0 & 44 & 23.6 \\
\hline Rumania & 30.3 & & & & 32.0 & 23 & \\
\hline Bulgaria & 22.8 & & & & 34.0 & 29 & 13.2 \\
\hline Spain & 37.0 & 33 & 14.9 & 20 & & 26 & 15.1 \\
\hline Serbia & 22.2 & & & & & 25 & 18.5 \\
\hline USA & & 33 & I 7.7 & 17.2 & & 16 & 17.1 \\
\hline Argentine & & 26 & I 7.7 & 8.0 & & 14 & \\
\hline Australia & & I7 & I6.5 & 5.8 & & & \\
\hline Canada & & 18 & I5.I & 8.3 & & & \\
\hline India & & 4 & & & & & \\
\hline
\end{tabular}

Sources: Liepmann 1938 Table IVb ('potential' protection, minimum tariff, used for the most favoured nation clause), League of Nations 1927 and Estevadeordal 1997 Table 8.

Notes: both Liepmann and the League of Nations (b) use a variant of UNT, averaging the duties on selected samples of representative commodities. The League of Nations takes into account 78 goods in 1913 and 258 in 1925, Liepmann 144 (divided into I9 classes). Liepmann's figures overestimate the actual protection because the denominator of his estimates (the 'world price' of each commodity) is proxied as f.o.b. prices from the main exporters instead of, correctly, by c.i.f. prices in the importing countries. League of Nations (d) is tariff revenue/imports (or NT).

Estevadeordal measures openness as:

$$
\text { OPE }=\sum\left|N_{j}\right| / \Sigma\left|N_{j}^{\star}\right|
$$

where the $N_{j}$ s are the actual net exports for 46 main commodities and $N_{j}^{\star} s$ are the predicted ones (cf. footnote 5). The coefficient should be the lower the more restricted trade is: here we report the inverse to make the results more comparable with the other measures. 